\title{
Emergency Planning in Switzerland
}

\author{
CRISTINA BIANCHI, PH.D. \\ Archivist of the city of Pully, and AAS representative in the Section of Professional Associations of the Interna- \\ tional Council on Archives, Archives of the City of Pully, av. du Prieuré 2, CH-1009 Pully, Switzerland \\ e-mail: Cristina.Bianchi@pully.ch
}

\section{Emergency Planning in Switzerland}

\begin{abstract}
Switzerland is a relatively safe and neutral country. The main risks of losing information, though, are through water and fire. Risk management includes emergency planning to quickly react against floods - lakes, rivers, cascades, glaciers and dams represent a wealthy use of hydropower in this alpine country - and fire or worse, arson. In practice, not many entities have yet thought of writing an emergency plan for saving their archives, and they find themselves lost when something happens, because they are unable to reactivate their business with vital documents in a couple of days... A special entity within the Swiss Civil Protection, called the Cultural Property Protection (PBC) specializes in training young men to protect cultural goods in their region. They will inspect the place, create an inventory with pictures, and propose an emergency plan. When an accident or natural disaster happens, they will be called on duty and asked to physically protect the goods by taking them out of the damaged building, ensure packing and store them in a safe place. How this works, under which legislation and what practical tools (inventory sheet, emergency evacuation sheet) the PBC uses to achieve this mission are the aspects that this article will develop.
\end{abstract}

Key words: Emergency planning, archives, legislation, inventory

\section{La pianificazione di emergenza in Svizzera}

\section{SINTESI}

La Svizzera è un paese neutrale e relativamente sicuro. I principali rischi di perdita di informazioni sono per contro rappresentati dall'acqua e dal fuoco. La gestione dei rischi comprende la pianificazione di emergenza per reagire rapidamente alle inondazioni - laghi, fiumi, cascate, ghiacciai e dighe consentono un abbondante utilizzo di energia idroelettrica in questo paese alpino - e al fuoco o, peggio, agli incendio dolosi. Nella pratica, molte organizzazioni non hanno ancora pensato di scrivere una mappa di emergenza per salvare i loro archivi, e si trovano sperduti quando succede qualcosa, perché non sono in grado di riavviare in pochi giorni la loro attività con documenti d'archivio essenziali... Un'entità speciale della Protezione civile svizzera, chiamata Protezione dei Beni Culturali (PBC), è specializzata nella formazione di giovani per proteggere i beni culturali della loro regione. Essi ispezionano il luogo, creano un inventario con foto, e propongono un piano di emergenza. Quando si verifica un incidente o un disastro naturale, vengono richiamati in servizio e gli si chiede di proteggere i beni culturali, portandoli fuori dall'edificio danneggiato, assicurarne l'imballaggio e conservarli in un posto sicuro. Come questo funziona, con quali leggi, quali sono gli strumenti pratici (foglio d'inventario, modulo di evacuazione di emergenza) che la PBC utilizza per realizzare questo compito sono gli aspetti che questo articolo svilupperà.

Parole chiave: Pianificazione di emergenza, archivi, legislazione, inventari

\section{Načrtovanje v primeru nesreč v Švici}

\section{IZVLEČEK}

Švica je relativno varna in nevtralna država. Glavno tveganje za izgubo podatkov predstavljata in ogenj. Upravljanje tveganj zajema načrtovanje $\mathrm{v}$ primeru nesreč, da bi se lahko hitro odzvali na poplave (jezera, reke, slapovi, ledeniki in jezovi predstavljajo bogat vir vodne energije v tej alpski državi) - ogenj ali še huje, požig. V praksi veliko institucij še ni pomislilo na pripravo nujnih ukrepov za zaščito svojega arhivskega gradiva. V primeru nesreče pa se soočajo z velikimi težavami, ker ne morejo $\mathrm{v}$ nekaj dneh aktivirati svojega poslovanja $\mathrm{z}$ vitalno dokumentacijo. Posebna skupina, kii deluje v okviru švicarske Civilne zaščite, in ki se imenuje Varovanje kulturnega premoženja (Cultural Property Protection - PBC) je specializirana za usposabljanje mladih moških za zaščito kulturne dediščine v njihovi regiji. Ti pregledajo lokacijo, pripravijo seznam $s$ slikami in predlagajo načrt 
zaščite $\mathrm{v}$ primeru izrednih razmer. Ko se nesreča ali naravna nesreča zgodi, so vpoklicani na dolžnost in zadolženi za fizično zaščito kulturnih dobrin, njihovo odstranitev iz poškodovane stavbe, zagotovitev embalaže in njihovo hranjenje na varnem mestu. Članek bo predstavil delo, zakonske podlage in praktična orodja (popis stanja, popis za evakuacijo v sili), ki jih PBC uporablja za doseganje svojega poslanstva.

Ključne besede: načrtovanje $\mathrm{v}$ primeru nesreč, arhivi, zakonodaja, inventar

\section{Introduction}

Switzerland is a relatively safe and neutral country. The main risks of losing information, though, are through water and fire. Risk management includes emergency planning to react quickly against floods - lakes, rivers, cascades, glaciers and dams represent a wealthy use of hydropower in this alpine country - and fire, or worse, arson.

Swiss firefighters are well trained and, through professional and volunteer call, they are ready to react immediately to these dangers, saving people and animals. If they have time, after they have accomplished their main duties, they will remove the (cultural) goods from the damaged buildings, according to emergency plans they have received from the administration.

In practice, not many entities have yet thought of writing an emergency plan for saving their archives, and they find themselves lost when something happens, because they are unable to reactivate their business with vital documents in a couple of days...

The Swiss Civil Protection - in French Protection Civile, in German: Zivilschutz, in Italian Protezione civile - is a body organized in 23 cantonal sections aimed at assisting the population in case of harmful events or disasters. It is one of the five pillars of the protection of the population, along with firefighters, police, technical services and health services (ambulances, hospitals, etc.) (for more see Internet 1).

A special entity within the Swiss Civil Protection (see Internet 2), called the Cultural Goods Protection - in French Protection des Biens Culturels (PBC), in German Kulturgüterschutz and Italian Protezione dei Beni Culturali - specializes in training young men, those who did not enter the compulsory national army but have to serve, to protect cultural goods in their region. They will inspect the place, create an inventory with pictures, and propose an emergency plan. When an accident or natural disaster happens, they will be called on duty and asked to physically protect the goods by taking them out of the damaged building, ensure packing and store them in a safe place.

\section{Legal foundations}

The inventory of cultural property has solid legal foundations.

The damage caused during the Second World War to many cultural properties have led many countries to conclude, on May 14th 1954, the Hague Convention for the Protection of Cultural Property in the Event of Armed Conflict. By acceding in 1962, Switzerland has undertaken to ensure and respect the protection of cultural property, both on its territory and that of other High Contracting Parties. The federal law of 6 October 1966 on the protection of cultural property during armed conflict fixed framework conditions of this commitment. It also included the protection of cultural goods during peacetime with preventive means. Switzerland also followed the Second Protocol of 1999 , enacted by UNESCO in 2004. The federal law and ordinance were subject to a comprehensive review by the Swiss Federal Council. They came into force on January 2015, adding an important paragraph on the concept of "safe haven": Among the important new provisions is the legal authority to provide a "safe haven" for the temporary storage of cultural property, including archives, seriously threatened in other countries, including in disaster and emergency situations. By enacting this much-needed law, Switzerland became the first country in the world to offer this official protection (Internet 3).

As part of the revision of the Swiss finding aid of cultural property of national and regional importance (PBC Inventory), uniform criteria were used for the classification of objects of national importance (A objects) throughout Switzerland. For lack of time and resources, it has not been possible 
to accurately assess also the large number of regionally significant objects (B objects) submitted by the cantons. Local objects of importance (C objects) are therefore only described locally by institutions and PBC. It includes, of course, archives.

\section{Emergency planning}

- Following various disasters, including flooding in Brig (1993) and the burning of the Junkerngasse in Bern, the Section of Protection of Cultural Property in the Federal Office for Protection of the Population found that people had not always planned or taken the basic safety precautions for the protection of immovable property. It was the same with the collections of movable property found in museums, archives, libraries, churches, etc. Therefore, the Federal Office for Protection of the population has developed a list of measures imposed to cultural property owners in order to limit significantly the damage that can cause a disaster.

- Buildings and cultural property contained therein are exposed to various dangers. It is possible to reduce significantly the risk by planning and taking simple and inexpensive precautions. The memorandum on the implementation of emergency plans is to facilitate this task to holders of cultural property; it offers checklists that must of course be adapted to local conditions. For cultural institutions that have already developed a response plan in case of disaster, the checklist is a good tool to check if the safety measures can be improved on some points (see Annex 1).

\section{PBC operations}

The local section of Cultural Property Protection calls its men on duty and, as one of its main tasks, prepares the emergency plan in three phases.

In the first phase, the local section of $\mathrm{PBC}$ obtains information and data from different entities, like the cantonal section of PBC, the architectural census department and the municipalities, in order to create a regional finding-aid of existing cultural properties.

In the second phase, it makes an appointment with the owners of the cultural goods, municipal general secretary, museum director, archivist, etc., and visits the place. The other possibility is that institutions have heard or know the possibility of such mission by PBC and call the section for help, lacking means to ask an archivist or a specialist. PBC then organizes several days with his men, who start documenting the cultural goods with three standard national forms.

In the third phase, the local PBC defines priorities concerning the removal of cultural goods and the protection of parts of the buildings. In case of an emergency, it will be not possible to evacuate all endangered cultural movables. In agreement with the experts, the owners of movable cultural property must immediately make choices and prepare the lists of goods to be evacuated as first priority and second priority.

These three forms allow the development of description and intervention plans for each object:

- Fiche de recensement PBC, PBC Enumeration form (Annex 2, Annex 3 as example)

- Fiche pour évacuation d'urgence PBC, PBC Emergency evacuation form (Annex 4, Annex 5 as example)

- Fiche d'inventaire PBC, PBC Inventory form (Annex 6)

First, georeferencing is important to optimize good understanding in data transmission:

- The General situation field asks for addresses and geographic location

- In order to keep regional logic, the inventory form and the emergency form will be uniquely numbered according to the national system MN-03 (Office de l'Information du Territoire)

- 12 numbers indicating the X and Y geographic coordinates (or GPS location)

- $\quad M$ or I (movable or immovable) - (A,B,C) level of filing of the object

- 7 numbers indicating the positioning of the property in the building, taking into account the level and the distribution of rooms and the location of the asset

- Example : 530094-161173/M-C/02-05-008 (second floor, $5^{\text {th }}$ room, $8^{\text {th }}$ object), according to the following rules : 

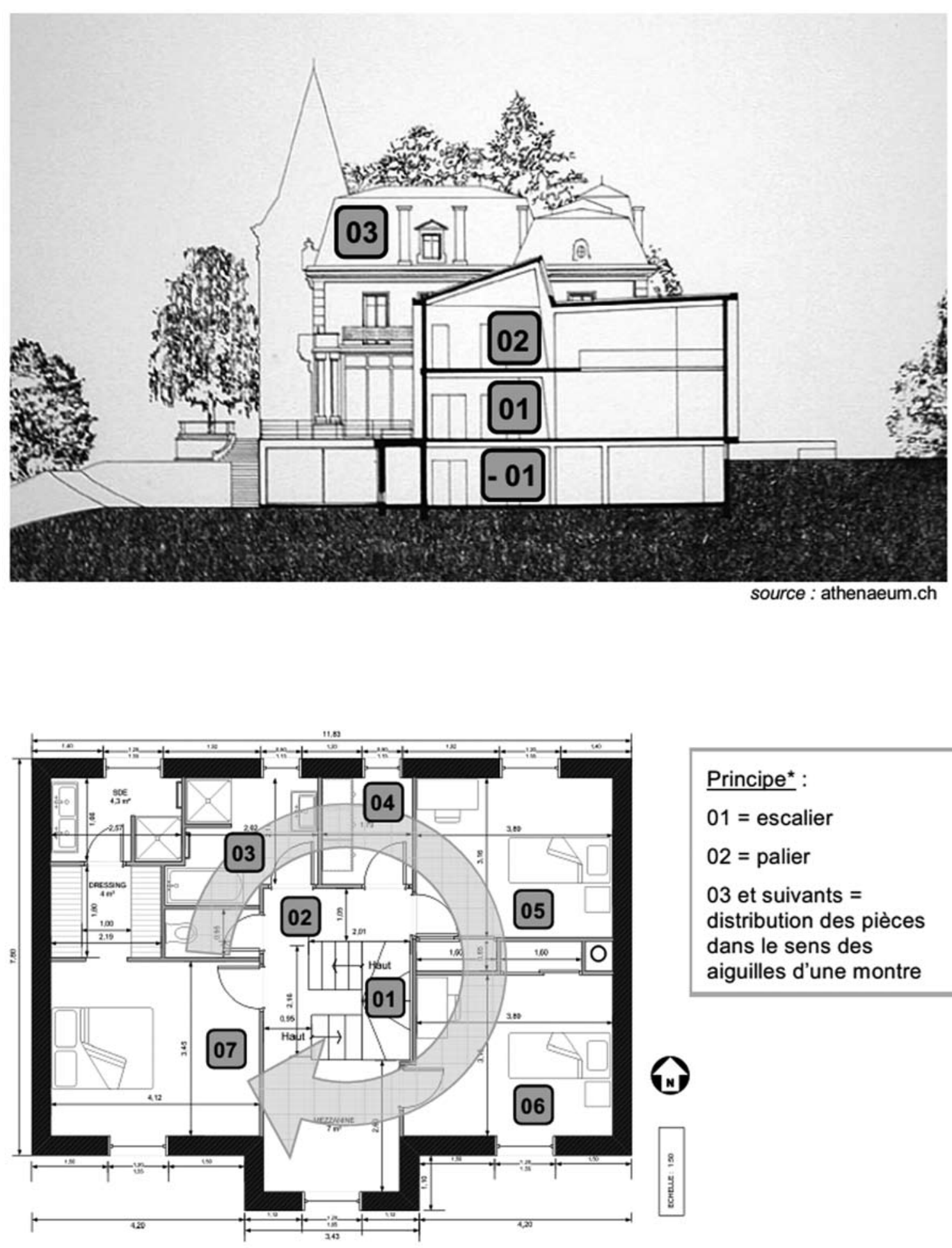

Principe ${ }^{\star}$ :

$01=$ escalier

02 = palier

03 et suivants $=$ distribution des pièces dans le sens des aiguilles d'une montre 


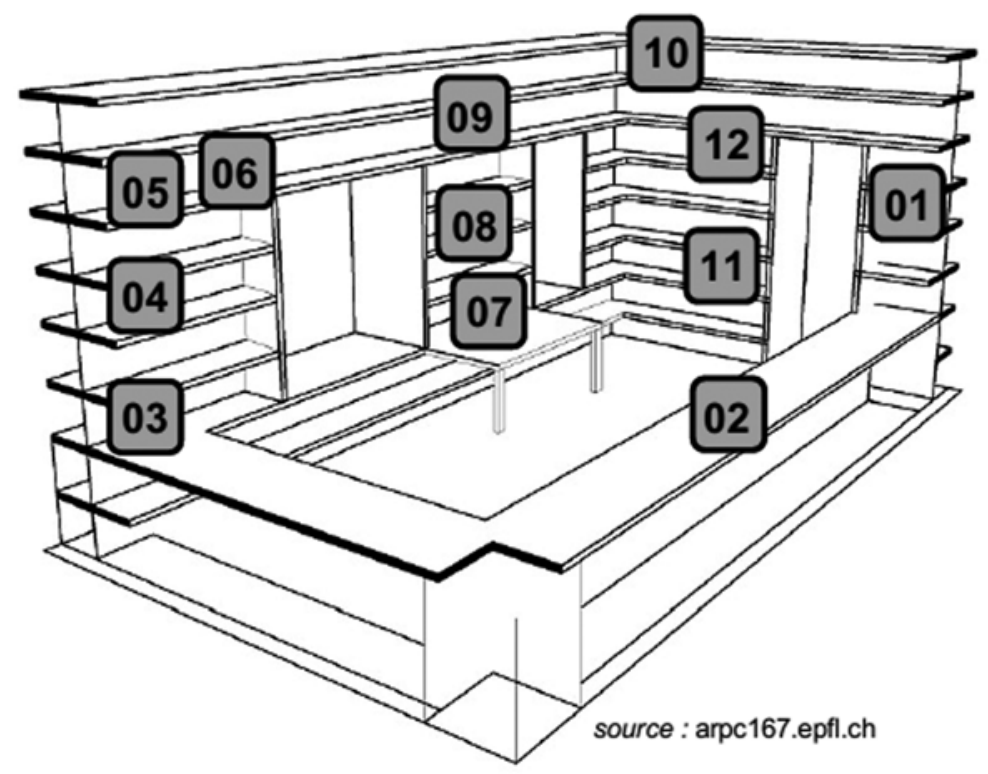

Second, the Description field has to be documented with text and precise dimensions, the kind of danger the object fears (water, fire, chemicals, weather disasters), and possibly a good picture of the object, or range of files and folders.

Third, the Bibliography field can be documented with information published on the object.

Fourth, the Measure field documents about the need for an evacuation or local protection (like sand sacks against a wall); how many men are needed to perform the job.

Fifth; the Suivi (follow-up) field will be filled by the person who wrote the document with his name and date.

The PBC Inventory form allows summarizing all the information on one document, looking like a list of objects. It is considered also as a security document, as it first identifies in an easier way the goods to evacuate in case of disaster. Secondly, an object well known by the public is hardly negotiable; safety documentation and an inventory sheet should be considered effective theft prevention measures. Moreover, in case of theft, inventory sheets will certify the origin of stolen goods.

These forms will be useful for the police and firefighters, in case of disaster or imminent danger. To be effective, this cooperation has to remain simple ... the first response is the Emergency evacuation form, developed by PBC to the intention of the archival repository, police and fire department. Its goal is to provide the first people who arrive on the site the information necessary for the evacuation of movable cultural property, in a simple visual form. Little PBC flags will be stuck on the premises to show where priority 1 goods are located.

It provides information on the recognition of the object: evacuation priorities, the number of people required, the specific hazards of the object, location and access.

The ORPC creates, keeps up to date and makes available to the Chief of intervention, if necessary, the emergency evacuation sheets specific to their cultural goods through PBC or fire department members and other on-call staff. It should be remembered that if the safeguarding of heritage justifies the implementation of such means, the principle of confidentiality in relation to the objects must be respec-

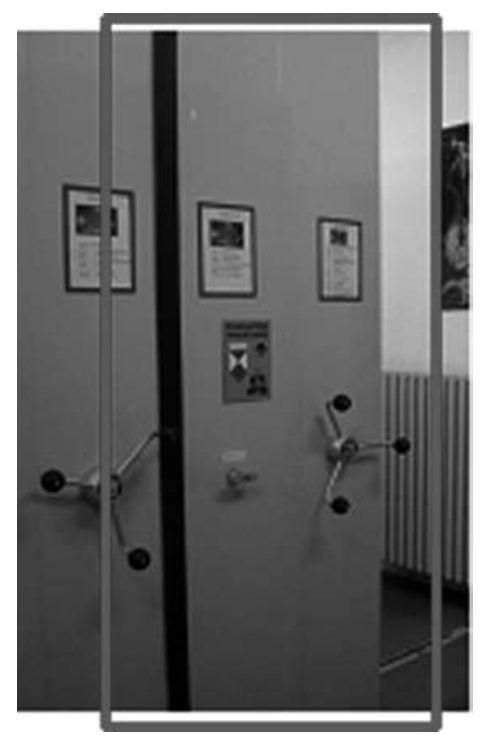
ted... The forms will not be spread out unnecessarily 
The ORPC also transmit to the ECA, the Cantonal establishment of insurance against fire and natural damage, geographical data about their cultural objects (address + national contact).

The ORPC stand ready to implement a cultural goods collector position near the disaster to receive the cultural goods that have just been evacuated. A special trailer containing all the material needed for protection (bubble wrap, scissors, tape, gloves, hygienic masks, boots, torch, etc.) is always ready for action. It also contains a foldable tent to be put up near the disaster place, in order for the militia to start working immediately.

Beforehand, institutions, in agreement with PBC, will have made a list of possible addresses of people to contact in case of emergency, addresses where to store movable property for a certain period, like cold storage in a nearby big store for wet paper to avoid moulding, and then specialized organisms restoring cultural property. An important element is to know where the key of the building is stored, and give it to the chief of the fire department when necessary.

Different institutions have decided to create a consortium to protect themselves against disaster, in order to work jointly and lower costs. The COSADOCA - Consortium for rescue of documentary heritage in case of disaster (Internet 4), was created in 2003 by the Archives cantonales vaudoises, the Federal Polytechnicum library of Lausanne (EPFL) and the Cantonal University Library of Lausanne. They organize regular fire and flooding exercises with the fire department, the police and the PBC, in order to train their staff and be ready for any emergency. The training of all the partners remains essential.

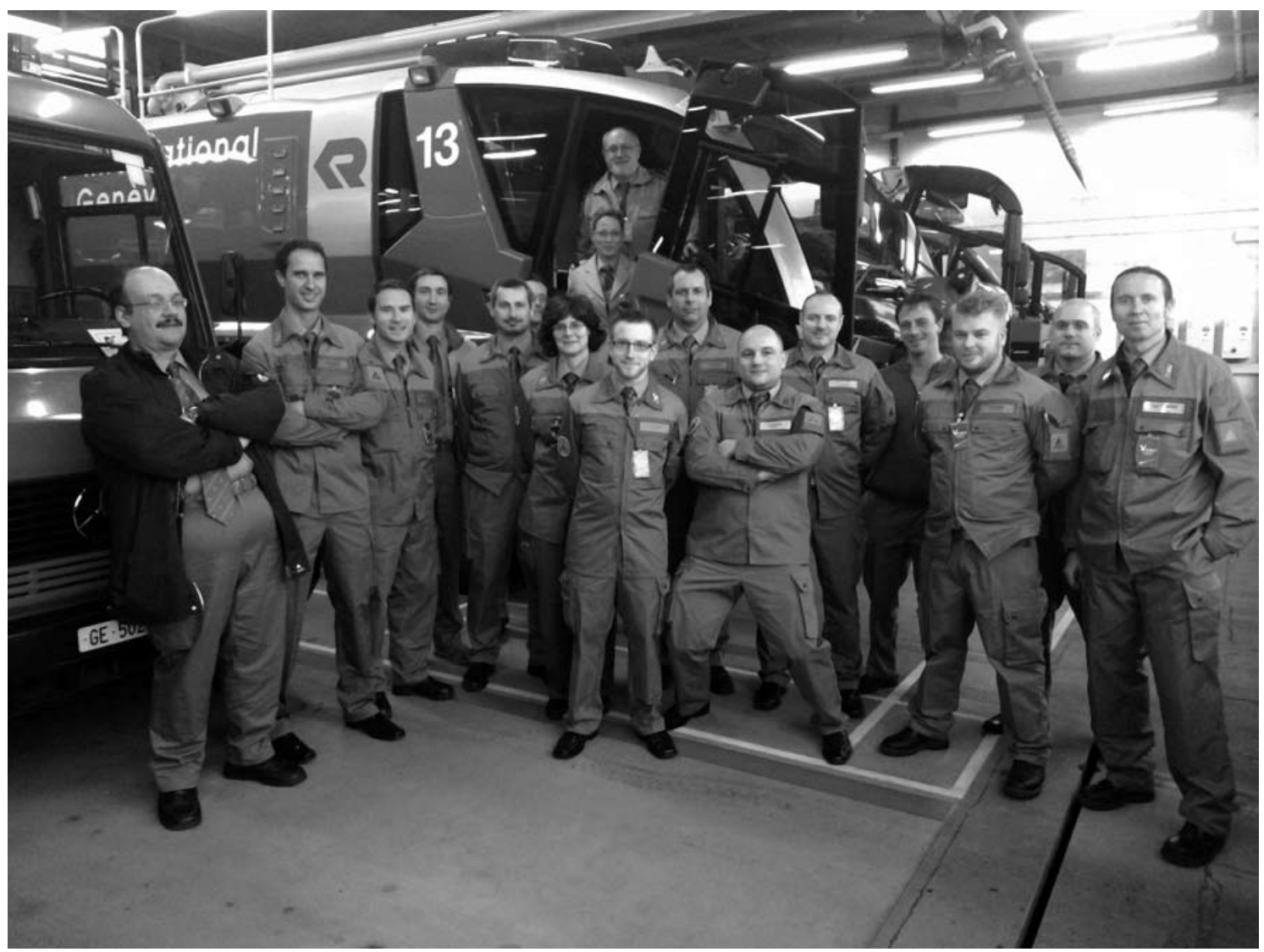

Picture 1: Local PBC training at the airport of Geneva, Switzerland

Security measures, comprehensive information and a prompt and correct response will certainly save many cultural properties in the event of a disaster. 


\section{References}

Internet 1:http://www.bevoelkerungsschutz.admin.ch/internet/bs/fr/home.html (visited on May $28^{\text {th }} 2015$ ).

Internet 2: http://www.bevoelkerungsschutz.admin.ch/internet/bs/fr/home/themen/kgs.html (visited on May $\left.28^{\text {th }} 2015\right)$.

Internet $\quad 3: \quad$ http://www.bevoelkerungsschutz.admin.ch/internet/bs/fr/home/dokumente/ mitteilungen/20131112a.html (visited on May $28^{\text {th }} 2015$ ).

Internet 4: http://www.cosadoca.ch/ (visited on May 28 $8^{\text {th }} 2015$ ).

\section{SUMMARY}

Switzerland is a relatively safe and neutral country. The main risks of losing information, though, are through water and fire. Risk management includes emergency planning to react quickly against floods - lakes, rivers, cascades, glaciers and dams represent a wealthy use of hydropower in this alpine country - and fire or worse, arson. Swiss firefighters are well trained and, through professional and volunteer call, they are ready to react immediately to these dangers, saving people and animals. If they have time, after they have accomplished their main duties, they will remove the (cultural) goods from the damaged buildings, according to emergency plans they have received from the administration. In practice, not many entities have yet thought of writing an emergency plan for saving their archives, and they find themselves lost when something happens, because they are unable to reactivate their business with vital documents in a couple of days... A special entity within the Swiss Civil Protection, called the Cultural Goods Protection - in French Protection des Biens Culturels (PBC), in German Kulturgüterschutz and Italian Protezione dei Beni Culturali - specializes in training young men, those who did not enter the compulsory national army but have to serve, to protect cultural goods in their region. They will inspect the place, create an inventory with pictures, and propose an emergency plan. When an accident or natural disaster happens, they will be called on duty and asked to physically protect the goods by taking them out of the damaged building, ensure packing and store them in a safe place. How this works, under which legislation and what practical tools the PBC uses to achieve this mission are the aspects that this article will develop.

Typology: 1.04 Professional Article

Submitting date: 13.03 .2015

Acceptance date: 09.04.2015

OFFICE FEDERAL DE LA PROTECTION DE LA POPULATION

Avril 98

PROTECTION DES BIENS CULTURELS EN CAS DE SINISTRE

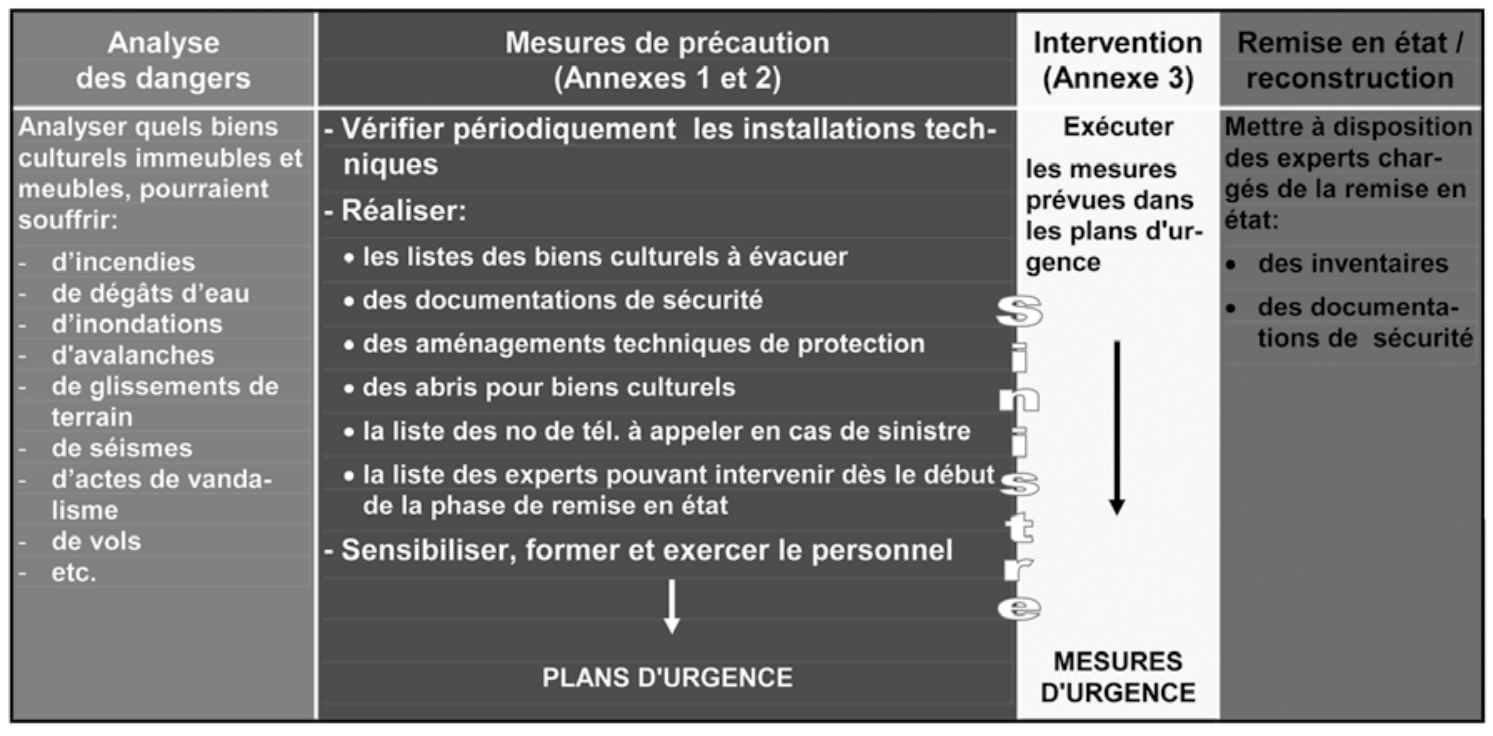


Cristina BIANCHI: Emergency Planning in Switzerland, 25-33
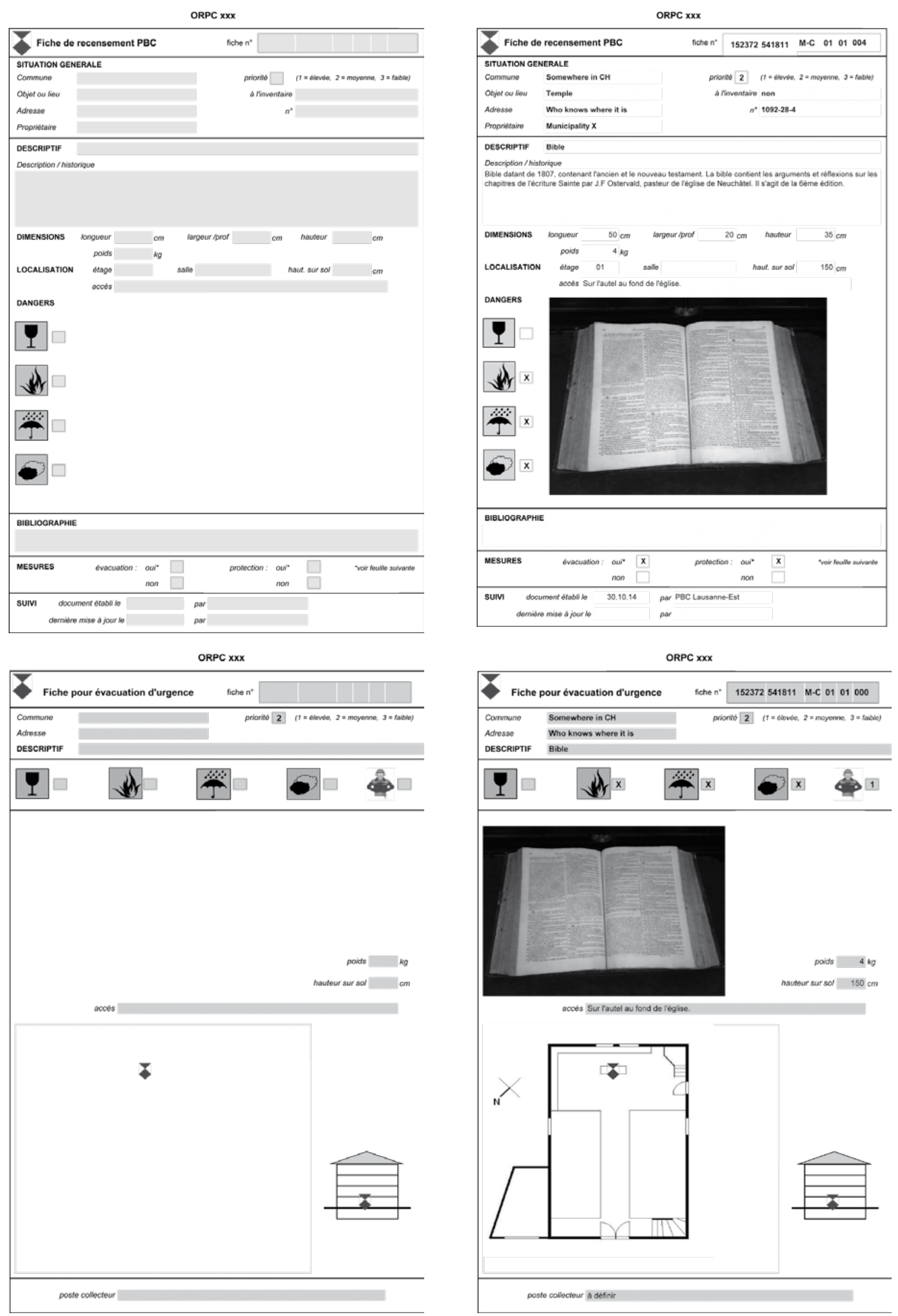
ATLANTI • 25 • $2015 \cdot$ n. 2

Cristina BIANCHI: Emergency Planning in Switzerland, 25-33

ORPC ...

dernière mise à jour le 26.05.2015

\begin{tabular}{|c|c|c|c|c|c|c|c|c|c|c|c|}
\hline \multicolumn{3}{|c|}{ fiche $n^{\circ}$} & \multicolumn{4}{|c|}{ désignation et emplacemement } & \multicolumn{5}{|c|}{ planification d'intervention } \\
\hline coord $\mathrm{X}$ & coord $Y$ & cat. & objet ou lieu & adresse & $n^{\circ}$ & commune, village ou lieu-dit & nbre & recens & évac & f.urg & annonce CTA \\
\hline & & & & & & & & & & & \\
\hline & & & & & & & & & & & \\
\hline & & & & & & & & & & & \\
\hline & & & & & & & & & & & \\
\hline & & & & & & & & & & & \\
\hline & & & & & & & & & & & \\
\hline & & & & & & & & & & & \\
\hline & & & & & & & & & & & \\
\hline & & & & & & & & & & & \\
\hline & & & & & & & & & & & \\
\hline & & & & & & & & & & & \\
\hline & & & & & & & & & & & \\
\hline & & & & & & & & & & & \\
\hline & & & & & & & & & & & \\
\hline & & & & & & & & & & & \\
\hline & & & & & & & & & & & \\
\hline & & & & & & & & & & & \\
\hline & & & & & & & & & & & \\
\hline & & & & & & & & & & & \\
\hline & & & & & & & & & & & \\
\hline & & & & & & & & & & & \\
\hline & & & & & & & & & & & \\
\hline & & & & & & & & & & & \\
\hline & & & & & & & & & & & \\
\hline & & & & & & & & & & & \\
\hline & & & & & & & & & & & \\
\hline & & & & & & & & & & & \\
\hline & & & & & & & & & & & \\
\hline & & & & & & & & & & & \\
\hline
\end{tabular}

page 1 de 2 
